\title{
Service user and caregiver involvement in mental health system strengthening in low- and middle-income countries: systematic review
}

Maya Semrau', Heidi Lempp², Roxanne Keynejad', Sara Evans-Lacko', James Mugisha³ , Shoba Raja ${ }^{4}$, Jagannath Lamichhane ${ }^{5}$, Atalay Alem ${ }^{6}$, Graham Thornicroft ${ }^{1}$ and Charlotte Hanlon ${ }^{6,1^{*}}$

\begin{abstract}
Background: The involvement of mental health service users and their caregivers in health system policy and planning, service monitoring and research can contribute to mental health system strengthening, but as yet there have been very few efforts to do so in low- and middle-income countries (LMICs).

Methods: This systematic review examined the evidence and experience of service user and caregiver involvement in mental health system strengthening, as well as models of best practice for evaluation of capacity-building activities that facilitate their greater participation. Both the peer-reviewed and the grey literature were included in the review, which were identified through database searches (MEDLINE, Embase, PsycINFO, Web of Knowledge, Web of Science, Scopus, CINAHL, LILACS, SciELO, Google Scholar and Cochrane), as well as hand-searching of reference lists and the internet, and a snowballing process of contacting experts active in the area. This review included any kind of study design that described or evaluated service user, family or caregiver (though not community) involvement in LMICs (including service users with intellectual disabilities, dementia, or child and adolescent mental health problems) and that were relevant to mental health system strengthening across five categories. Data were extracted and summarised as a narrative review.

Results: Twenty papers matched the inclusion criteria. Overall, the review found that although there were examples of service user and caregiver involvement in mental health system strengthening in numerous countries, there was a lack of high-quality research and a weak evidence base for the work that was being conducted across countries. However, there was some emerging research on the development of policies and strategies, including advocacy work, and to a lesser extent the development of services, service monitoring and evaluation, with most service user involvement having taken place within advocacy and service delivery. Research was scarce within the other health system strengthening areas.

Conclusions: Further research on service user and caregiver involvement in mental health system strengthening in LMICs is recommended, in particular research that includes more rigorous evaluation. A series of specific recommendations are provided based on the review.
\end{abstract}

Keywords: Capacity-building, Service users, Caregivers, Health systems, Mental health, Low- and middle-income countries

\footnotetext{
* Correspondence: charlotte.hanlon@kcl.ac.uk

${ }^{6}$ Department of Psychiatry, Addis Ababa University, College of Health

Sciences, School of Medicine, Addis Ababa, Ethiopia

'King's College London, Institute of Psychiatry, Psychology \& Neuroscience,

16 De Crespigny Park, London, SE5 8AF, UK

Full list of author information is available at the end of the article
} 


\section{Background Rationale}

There is wide recognition in principle about the importance of involving service users and their caregivers in health system policy and planning processes, service monitoring and health research. There is also some evidence from high-income countries that their involvement can directly lead to improved mental health system strengthening [1-5]. Participatory policy-making, planning and service monitoring is of particular importance in the field of mental health, where a large majority of people with mental disorders or psychosocial disabilities do not receive any effective treatment or care, and may at times receive treatment against their will [6]. To avoid fragmented and tokenistic inclusion of service users and caregivers in planning, or their marginalisation, and to facilitate meaningful and effective contributions, it is necessary for professionals working within the formal health system to share responsibility with representative organisations. Mental health service user networks have been emerging and are on the increase globally [7, 8]. However, to date there have been very few reports of efforts to involve service users and caregivers in mental health service strengthening in low- and middle-income countries (LMICs). Yet this information is vital in planning capacity-building programmes for service users and caregivers to effectively participate in improving mental health programmes.

This systematic review was undertaken as part of the 'Emerging mental health systems in LMICs' (Emerald) programme [9], which aims to improve mental health outcomes by generating evidence and capacity to strengthen mental health system performance in six African and Asian LMICs (Ethiopia, India, Nepal, Nigeria, South Africa and Uganda). One of the objectives of the Emerald programme is to empower and equip service users and caregivers to participate more fully and effectively in the mental health system, for example at the level of (i) mental health policy-making and planning processes, (ii) service development and monitoring, and (iii) mental health research. This review served to provide an evidence base to inform the Emerald programme's capacity-building activities for service users and caregivers.

\section{Objectives}

The objectives for this systematic review were: (i) to systematically synthesise the current evidence and experience base for models of involvement of mental health service users/caregivers in mental health policy-making, mental health service development, quality monitoring and evaluation of services, and mental health research in LMICs; and (ii) to identify models of best practice for evaluation of capacity-building of service users and caregivers to facilitate greater involvement in these mental health system strengthening activities.

\section{Methods \\ Eligibility criteria}

The PRISMA checklist is included in Additional file 1. A protocol for the review is available upon request from the authors. Given the scarcity of evidence from LMICs with respect to service user involvement in mental health care more generally, and since initial pilot literature searches carried out by the authors did not identify many relevant papers, a limited number of pertinent resources was anticipated. A broad eligibility framework was therefore adopted, and both peer-reviewed journal papers and grey literature (such as books, unpublished reports, website resources, or training materials) were included in the review.

Whilst the primary focus of the review was capacitybuilding of service user and caregivers in mental health system strengthening, and the evaluation of capacitybuilding, a secondary focus was a broader examination of service user and caregiver involvement per se. We therefore included any kind of study design, which reviewed or reported on evaluation or experience of service user (i.e. service users with any kind of mental health problem, including those with intellectual disabilities, dementia, or child and adolescent mental health problems), family or caregiver (though not community) involvement in LMICs, and which were relevant to mental health system strengthening. This entailed direct involvement of service users and caregivers in: (i) development of policies or strategies; (ii) planning or development of services; (iii) training of health workers in mental health care; (iv) service monitoring, evaluation or quality control; or (v) mental health research. Given the dearth of evidence of service user and caregiver involvement in mental health systems, the search was expanded to also include involvement in service delivery and/or support groups, even though their applicability to mental health system strengthening was considered to be limited, unless the support groups contained an advocacy, empowerment or mobilisation component. No studies were excluded based on the type of service, for example whether they were delivered within the formal health system or through alternative avenues.

Although an explicit evaluation of service user/caregiver involvement was required within the original criteria for inclusion, a post hoc decision was made to also include studies that described service user/caregiver involvement in mental health system strengthening according to the categories outlined above, even when there was no clear evaluation strategy. Papers written in English, Spanish, Portuguese, French or German were included. Studies that reported on data solely from high-income countries were excluded. 


\section{Search strategy, study selection and data extraction}

To identify relevant peer-reviewed literature, we searched the following databases: MEDLINE [1946 to December 2013], Embase [1974 to December 2013], PsycINFO [1806 to December 2013], Web of Knowledge, Web of Science, Scopus, CINAHL, LILACS, SciELO, Google Scholar and Cochrane [all from the start date of the database to December 2013]. The search strategy is detailed in Table 1.

Further relevant literature was identified by: (i) handsearching reference lists (for example in relevant reviews or journal papers); (ii) a snowballing process of contacting experts active in the area; and (iii) by searching the internet (through use of the Google search engine). Two researchers reached consensus on whether resources that were identified via the grey literature process were eligible for inclusion into the review. Any non-peerreviewed grey literature found during this search fed into the 'Discussion' section of this paper.

For literature that was identified through the database search, each of the titles and abstracts of papers that the search generated were assessed by two independent reviewers. Any paper that was considered to be relevant by either of the two reviewers was included for full-text review. Full-text papers were then screened by two independent reviewers. Where there was disagreement between the independent reviewers of the full-text articles, two senior reviewers made the final decision as to whether the paper fulfilled the inclusion criteria.

A data extraction form (see Tables 2, 3, 4 and 5 for the data obtained from the completed forms) was designed prior to running the review, and the data were extracted by two independent reviewers [one reviewer was used for papers that were written in languages other than English]. The data taken from selected papers was not amenable to statistical synthesis through meta-analysis and was, instead, synthesised into a narrative review, as data were heterogeneous between studies and much of the data were qualitative.

\section{Quality assessment of papers}

To assess the quality of papers that were included in the review, for studies containing quantitative data, the 'Quality assessment tool for quantitative studies' by the 'Effective Public Health Practice Project' (EPHPP) [10, 11] was used (see also http://www.ephpp.ca/tools.html) (see footnote of Table 2 for the eight categories that the methodology includes). A global quality assessment rating of 'strong,' 'moderate' or 'weak' was then assigned based on the responses within each of the eight categories. For studies containing qualitative data, twelve review criteria were used, based on those suggested in the literature on qualitative research, as described in Harden et al. [12] (see footnote of Table 4 for the twelve review criteria). Where studies included both quantitative and qualitative data, an assessment was made for both types of data, using the methodologies described above (see Table 3). No quality assessment was made for nondata-based descriptive studies (see Table 5), or for (non-peer-reviewed) grey literature.

\section{Ethics statement}

No ethical review was required as there was no research on human participants.

\section{Results}

\section{Study selection and characteristics}

Figure 1 displays a flow diagram showing the process that was employed in the selection of peer-reviewed articles. In total, 20 papers were included in the narrative review.

The characteristics of the peer-reviewed studies that were eligible for inclusion are shown in Tables 2, 3, 4 and 5 . Of the 20 studies, only four included an explicit evaluation of service user/caregiver involvement and thus met our original criteria for inclusion. A further six studies included an evaluation component (though no evaluation of service user or caregiver involvement), six were descriptive data-based studies, and four studies were non-data-based descriptive pieces. Only one (cluster)randomised controlled trial (RCT) was identified. Across studies, twelve countries were included that were uppermiddle income at the time of publication (seven studies from South America, two from Asia, one from Africa, one from Europe, and one from Europe/Asia [Russia]), five lower middle-income countries (three studies from Asia, one from Africa, and one from Europe), and eight countries that were low-income at the time of publication (five from Africa and three from Asia) (according to the World Bank, see http://data.worldbank.org/); a further study included data from 63 different countries or regions [13]. The majority of studies $(n=16)$ included at least one author from a LMIC; four did not [13-16]. Of the 20 papers, eleven were published after 2010, and nine studies were published between 2000 and 2010. Fifteen papers were published in English, three in Spanish [17-19] and two in Portuguese [20, 21].

In accordance with the type of data collected in studies, eight studies included quantitative outcomes and eleven studies included qualitative outcomes/evaluation methods (of which three studies included both types of outcomes/ evaluation methods) (see Tables 2, 3, 4 and 5). Of these studies, only four (two quantitative $[22,23]$ and two qualitative $[24,25])$ included outcomes that clearly assessed how service user or caregiver involvement impacted on service users and/or caregivers themselves (for example, in terms of number of hospitalisations, mental health status or coping capacities of service users, caregiver burden). Five studies (two quantitative [26, 27], three qualitative 
Table 1 Search strategy used in the database search

The following key concepts were used for the search: 'Service users' AND 'health system and services/research' AND 'mental health' AND 'LMICs'

\section{Service users}

\#1 Search: (exp Patient Participation/OR exp Consumer Participation/) OR (patient involvement OR client involvement OR service user involvement OR client participation OR service user participation OR patient participation OR service user engagement OR patient engagement OR service user coproduction OR patient co-production).mp

\section{Health system and services research}

\#2 Search: (exp Delivery of Health Care/ OR exp Health Policy/ OR exp Health Services/ OR exp Mental Health Services/OR exp Community Mental Health Services/ OR exp Community Health Planning) OR (delivery of health care OR health care delivery OR health system strengthening OR health policy OR health policies OR health system OR health systems OR health services OR mental health system OR mental health systems OR mental health services OR community mental health services).mp. OR Exp Research/ OR research.mp.

\section{Mental health}

\#3 Search: (exp Mental health/ OR exp Mental Disorders/) OR ("drug abuse" OR "drug addict*" OR "drug depend* *" OR "drug dependence*" OR "drug withdrawal" OR "drug abuse") OR ("addictive disease*" OR "addictive disorder*") OR ("alcoholic patient *" OR "alcoholic subject*" OR alcoholism OR "alcohol dependent*" OR "alcohol dependence*" OR "fetal alcoho*" OR "prenatal alcohol*" OR "chronic ethanol*" OR "chronic* alcohol*" OR "alcohol withdrawal" OR "ethanol withdrawal") OR("caffeine dependent*" OR "caffeine dependence" OR "caffeine addiction" OR (caffeine AND addict*) OR "caffeine withdrawal") OR (((cocaine OR heroin OR cannabis OR mdma OR ecstasy OR morphine*) AND (abuse OR depend* OR dependent* OR dependence* OR addict* OR addicts OR addicted OR addiction* OR withdrawal) OR methadone) OR (addiction OR addictive OR "substance abuse" OR "withdrawal syndrome" OR psychoactive*) OR ((schizophrenia OR schizophrenic) OR Schizotyp* OR ((Delusional OR paranoid) AND disorder*) OR hallucination* OR Psychotic OR Schizoaffective OR psychosis) OR (((manic OR bipolar OR mood) AND disorder*) OR (depressive AND (disorder* OR episode*)) OR "depressive symptom*" OR hypomania OR mania* OR ((major OR psychotic OR disorder*) AND depression) OR "suicide attempt*" OR suicidal* OR cyclothymia OR Dysthymia) OR (((anxiety OR panic OR "Obsessive-compulsive" OR adjustment OR conversion OR dissociative OR Somatoform OR Somatization OR neurotic) AND disorder*) OR ("hypochondriasis*" OR "body dysmorphic disorder*" OR "pain disorder*") OR agoraphobia OR "social phobia*" OR "Post-traumatic stress" OR "stress disorder*") OR ("Eating disorder*" OR "Anorexia nervosa" OR "Bulimia nervosa" OR "sleep disturbance" OR (sexual AND (disorder* OR dysfunction)) OR ((postnatal OR postpartum) AND depression) OR ((antidepressant* OR laxative* OR analgesic* OR psychotropic* OR vitamin* OR steroids OR hormone*) AND abuse) OR ((insomnia OR sleepiness OR "sleep disturbance") NOT (apnea OR "side effect*" OR parkinson* OR alzheimer OR neurodegenerat* OR cancer OR obesity OR obese*)) OR (hypersomnia NOT narcolepsy) OR ((sleep OR night) AND terror*) OR nightmare* OR ((disorder* AND (personality OR identity OR impulse* OR impulsive* OR impulsivity)) OR asocial OR antisocial OR psychopathic OR anxious OR narcissi* OR "Pathological gambling" OR pyromania* OR Trichotillomania OR Psychosexual OR ("Munchhausen syndrome")) OR ("Pervasive developmental disorder*" OR autism OR autistic* OR "Rett* syndrome" OR "Asperger* syndrome") OR ((Hyperkinetic OR Conduct OR Emotional OR tic) AND disorder*) OR (anxiety AND (separation OR phobic OR social)) OR (hyperactivity AND (disorder* OR syndrome)) OR "Tourette syndrome" OR "Tourette's syndrome") OR ((Mental AND (disorder* OR illness OR health OR health condition OR distress)) OR "psychological distress" OR "psychiatric disorder ") OR(Nervousness OR "nervous tension" OR Irritability) OR anorexia OR (neurosis OR neuroses OR psychoses) OR ("mental confusion*") OR ("mental disability*) OR ("mental capacity*") OR ((psychiatric OR mental) AND (comorbidity OR comorbid)) OR psychiatry OR psychology))

\section{LMICs}

\#4 Search: (developing OR less developed OR under developed OR underdeveloped OR middle income OR low income OR lower income).mp. AND (countr* OR nation* OR population* or world).mp.

OR

(transitional OR developing OR less developed OR lesser developed OR under developed OR underdeveloped OR middle income OR low income OR lower income).mp. AND (economy OR economies).mp.

OR

((low*).mp. AND (gdp OR gnp OR gross domestic OR gross national).mp.) OR (Imic OR Imics OR lamics OR lamic OR third world OR lami countries OR lami country).mp. OR (transitional country OR transitional countries).mp.ORExp Developing Countries/

OR

(Afghanistan or Albania or Algeria or Angola or Antigua or Barbuda or Argentina or Armenia or Armenian or Aruba or Azerbaijan or Bangladesh or Benin or Byelarus or Byelorussian or Belarus or Belorussian or Belorussia or Belize or Bhutan or Bolivia or Bosnia or Herzegovina or Hercegovina or Botswana or Brazil or Bulgaria or Burkina Faso or Burkina Fasso or Upper Volta or Burundi or Urundi or Cambodia or Khmer Republic or Kampuchea or Cameroon or Cameroons or Cameron or Camerons or Cape Verde or Central African Republic or Chad or Chile or China or Colombia or Comoros or Comoro Islands or Comores or Mayotte or Congo or Zaire or Costa Rica or Cote d Ivoire or Ivory Coast or Croatia or Cuba or Cyprus or Czechoslovakia or Czech Republic or Slovakia or Slovak Republic or Djibouti or French Somaliland or Dominica or Dominican Republic or East Timor or East Timur or Timor Leste or Ecuador or Egypt or El Salvador or Eritrea or Estonia or Ethiopia or Fiji or Gabon or Gabonese Republic or Gambia or Gaza or Georgia Republic or Georgian Republic or Ghana or Gold Coast or Grenada or Guatemala or Guinea or Guam or Guiana or Guyana or Haiti or Honduras or India or Maldives or Indonesia or Iran or Iraq or Jamaica or Jordan or Kazakhstan or Kazakh or Kenya or Kiribati or Korea or Kosovo or Kyrgyzstan or Kirghizia or Kyrgyz or Kirghiz or Kirgizstan or Lao PDR or Laos or Latvia or Lebanon or Lesotho or Basutoland or Liberia or Libya or Lithuania or Macedonia or Madagasca or Malagasy or Malaysia or Malaya or Malay or Sabah or Sarawak or Malawi or Nyasaland or Mali or Marshall Islands or Mauritania or Mauritius or Agalega Islands or Mexico or Micronesia or Middle East or Moldova or Moldovia or Moldovian or Mongolia or Montenegro or Morocco or Ifni or Mozambique or Myanmar or Myanma or Burma or Namibia or Nepal or Netherlands Antilles or New Caledonia or Nicaragua or Niger or Nigeria or Mariana Islands or Oman or Muscat or Pakistan or Palau or Palestine or Panama or Paraguay or Peru or Philippines or Philipines or Phillipines or Phillippines or Romania or Rumania or Roumania or Russia or Russian or Rwanda or Ruanda or Saint Kitts or St Kitts or Nevis or Saint Lucia or St Lucia or Saint Vincent or St Vincent or Grenadines or Samoa or Samoan Islands or Navigator Island or Navigator Islands or Sao Tome or Senegal or Serbia or Montenegro or Seychelles or Sierra Leone or Slovenia or Sri Lanka or Ceylon or Solomon Islands or Somalia or Somaliland or South Africa or Sudan or Suriname or Surinam or Swaziland or Syria or Tajikistan or Tadzhikistan or Tadjikistan or Tadzhik or Tanzania or Thailand or Togo or Togolese or Tonga or Trinidad or Tobago or Tunisia or Turkey or Turkmenistan or Turkmen or Uganda or Ukraine or Uruguay or USSR or Soviet Union or Union of Soviet Socialist Republics or Uzbekistan or Uzbek or Vanuatu or New Hebrides or Venezuela or Vietnam or Viet Nam or West Bank or Yemen or Yugoslavia or Zambia or Zimbabwe or Rhodesia).mp. 
Table 2 Overview of quantitative data studies included in the review

\begin{tabular}{|c|c|c|c|c|c|c|c|c|}
\hline Authors & $\begin{array}{l}\text { Countries } \\
\text { involved }\end{array}$ & Study design & $\begin{array}{l}\text { Participant group and } \\
\text { sample size }\end{array}$ & $\begin{array}{l}\text { Area and level of } \\
\text { service user } \\
\text { involvement }\end{array}$ & $\begin{array}{l}\text { Type of evaluation of } \\
\text { involvement (if any) }\end{array}$ & Outcomes $^{a}$ & Summary of findings & $\begin{array}{l}\text { Assessment of } \\
\text { quality }^{\mathrm{b}}\end{array}$ \\
\hline $\begin{array}{l}\text { Aznar et al. } \\
\text { (2012) [26] }\end{array}$ & $\begin{array}{l}\text { Argentina } \\
\text { and Chile }\end{array}$ & $\begin{array}{l}\text { Development of a } \\
\text { scale for the rights of } \\
\text { people with intellectual } \\
\text { disabilities (ID); cross- } \\
\text { sectional comparison } \\
\text { between people with } \\
\text { ID and controls }\end{array}$ & $\begin{array}{l}37 \text { participants in } \\
\text { Delphi group; } 51 \text { in } \\
\text { pilot study; } 705 \text { people } \\
\text { with ID in Chile and } \\
524 \text { control University } \\
\text { students }\end{array}$ & $\begin{array}{l}\text { People with ID and } \\
\text { their families involved } \\
\text { in the development of } \\
\text { the scale (Delphi group } \\
\text { and pilot study) }\end{array}$ & None & $\begin{array}{l}\text { Other (study: scale } \\
\text { development): Rights } \\
\text { fulfilment score on the } \\
\text { devised scale plus } 10 \\
\text { individual items on } \\
\text { scale; Cronbach's alpha }\end{array}$ & $\begin{array}{l}\text { The scale may be an } \\
\text { appropriate scale to } \\
\text { monitor rights, } \\
\text { though further } \\
\text { development needed. } \\
\text { Family relationships, } \\
\text { community } \\
\text { participation, living } \\
\text { arrangements and } \\
\text { level of disability } \\
\text { affect experience of } \\
\text { rights among people } \\
\text { with ID. With } \\
\text { structured supports, } \\
\text { people with ID appear } \\
\text { able to exercise their } \\
\text { rights to a level } \\
\text { comparable to peers } \\
\text { without ID. }\end{array}$ & weak \\
\hline $\begin{array}{l}\text { Malakouti et } \\
\text { al. (2009) } \\
\text { [22] }\end{array}$ & Iran & $\begin{array}{l}\text { Non-randomised } \\
\text { quasi-experimental } \\
\text { intervention }\end{array}$ & $\begin{array}{l}12 \text { psychology } \\
\text { graduates, plus } 9 \\
\text { Consumers' Family } \\
\text { Members (CFM) of } \\
\text { people with } \\
\text { schizophrenia trained } \\
\text { as case managers, of } \\
\text { which } 6 \text { persons (i.e. } \\
12 \text { in total) from each } \\
\text { group were selected } \\
\text { as case managers; } 129 \\
\text { people with } \\
\text { schizophrenia case } \\
\text { managed }\end{array}$ & $\begin{array}{l}\text { Training of CFM to be } \\
\text { a case management } \\
\text { group with } 6 \text { family } \\
\text { members case } \\
\text { managing patients } \\
\text { with schizophrenia }\end{array}$ & $\begin{array}{l}\text { CFM group had the } \\
\text { potential to be trained } \\
\text { as case-managers in } \\
\text { mental health, espe } \\
\text { cially if limited } \\
\text { resources. }\end{array}$ & $\begin{array}{l}\text { Service user/caregiver: } \\
\text { Number of } \\
\text { hospitalisations of } \\
\text { people case-managed } \\
\text { by CFMs versus mental } \\
\text { health workers plus } \\
\text { caregiver burden, } \\
\text { knowledge, Quality of } \\
\text { Life, general health of } \\
\text { caregivers; psychopath } \\
\text { ology and social skills } \\
\text { of schizophrenia } \\
\text { patients }\end{array}$ & $\begin{array}{l}\text { Most clinical variables } \\
\text { were improved } \\
\text { without significant } \\
\text { differences between } \\
\text { groups. The } \\
\text { hospitalization rate } \\
\text { was reduced by } 67 \% \text {. } \\
\text { Selection of family of } \\
\text { people with severe } \\
\text { mental illness should } \\
\text { be done with } \\
\text { scrutinized criteria } \\
\text { considering the } \\
\text { refusal rate of } 35 \% \text { of } \\
\text { the subjects in the } \\
\text { CFM group (17 \% in } \\
\text { mental health } \\
\text { workers). }\end{array}$ & weak \\
\hline $\begin{array}{l}\text { McBain et } \\
\text { al. (2012) } \\
\text { [13] }\end{array}$ & $\begin{array}{l}63 \text { LAMICS } \\
\text { and } \\
\text { country } \\
\text { regions }\end{array}$ & $\begin{array}{l}\text { Data from countries } \\
\text { that completed WHO's } \\
\text { Assessment Instrument } \\
\text { for Mental Health } \\
\text { Systems (WHO-AIMS); } \\
\text { multiple regression } \\
\text { analyses to investigate } \\
\text { role of mental health } \\
\text { legislation, human }\end{array}$ & $\begin{array}{l}63 \text { countries/regions, } \\
\text { and advocacy groups }\end{array}$ & $\begin{array}{l}\text { Study used 'yes/no' } \\
\text { questions identifying } \\
\text { whether associations of } \\
\text { service users or people } \\
\text { affected by mental } \\
\text { illness were involved } \\
\text { in the formulation of } \\
\text { mental health } \\
\text { legislation }\end{array}$ & None & $\begin{array}{l}\text { System (country)-level: } \\
\text { Access to psychotropic } \\
\text { medicines (availability } \\
\text { and affordability) } \\
\text { (multiple regression } \\
\text { analyses) }\end{array}$ & $\begin{array}{l}\text { Participation of family- } \\
\text { based organizations in } \\
\text { the development of } \\
\text { mental health } \\
\text { legislation associated } \\
\text { with } 17 \% \text { greater } \\
\text { availability of psycho } \\
\text { tropic medication }\end{array}$ & $\begin{array}{l}\text { N/A (as between- } \\
\text { country comparison } \\
\text { rather than } \\
\text { individual-level } \\
\text { comparison) }\end{array}$ \\
\hline
\end{tabular}

legislation, human

rights implementations, ology and social skills of schizophrenia 
Table 2 Overview of quantitative data studies included in the review (Continued)

\begin{tabular}{|c|c|c|c|c|c|c|c|c|}
\hline & & $\begin{array}{l}\text { mental health care } \\
\text { financing, human } \\
\text { resources, and role of } \\
\text { advocacy groups on } \\
\text { availability and affordability } \\
\text { of psychotropic medicines }\end{array}$ & & & & & & \\
\hline $\begin{array}{l}\text { Singh et al. } \\
\text { (2005) [30] }\end{array}$ & India & $\begin{array}{l}\text { Semi-structured } \\
\text { questionnaire on efficiency, } \\
\text { punctuality and behaviour } \\
\text { of doctors and other staff, } \\
\text { waiting time, supply of } \\
\text { drugs, and cleanliness of } \\
\text { hospital etc. }\end{array}$ & $\begin{array}{l}88 \text { service users and } 20 \\
\text { family members from } \\
\text { National Drug } \\
\text { dependence Treatment } \\
\text { Centre Outpatients }\end{array}$ & $\begin{array}{l}\text { Answering of } \\
\text { semi-structured } \\
\text { questionnaire }\end{array}$ & Not described & $\begin{array}{l}\text { Other (satisfaction data } \\
\text { (service users and } \\
\text { caregivers)): e.g. } \\
\text { efficiency, waiting staff, } \\
\text { quality of care, general } \\
\text { atmosphere, } \\
\text { stigmatisation, } \\
\text { communication }\end{array}$ & $\begin{array}{l}\text { Over } 90 \% \text { of patients } \\
\text { and their attendants } \\
\text { appreciated services } \\
\text { provided. } 90-94 \% \\
\text { were satisfied with } \\
\text { the supply of drugs, } \\
\text { quality of clinical care } \\
\text { and cleanliness of the } \\
\text { hospital. Measures for } \\
\text { improvement were } \\
\text { also suggested. }\end{array}$ & weak \\
\hline $\begin{array}{l}\text { Tripathy et } \\
\text { al. (2010) } \\
\text { [23] }\end{array}$ & India & $\begin{array}{l}\text { Cluster-randomised c } \\
\text { ontrolled trial }\end{array}$ & $\begin{array}{l}36 \text { clusters in three } \\
\text { districts in Jharkhand } \\
\text { and Orissa ( } 18 \text { clusters } \\
\text { each per intervention } \\
\text { and control arm); } \\
\text { participants were } \\
\text { women who were } \\
\text { between } 15 \text { to } 49 \text { years } \\
\text { old, living in the } \\
\text { project area, and had } \\
\text { given birth during the } \\
\text { 3-year study period }\end{array}$ & $\begin{array}{l}\text { Women in intervention } \\
\text { clusters participated in } \\
\text { groups to support } \\
\text { participatory action and } \\
\text { learning for women, } \\
\text { and to facilitate the } \\
\text { development and } \\
\text { implementation of } \\
\text { strategies to address } \\
\text { maternal and newborn } \\
\text { health problems }\end{array}$ & $\begin{array}{l}\text { No direct evaluation of } \\
\text { involvement, though } \\
\text { women's group } \\
\text { intervention included } \\
\text { an assessment cycle. } \\
\text { Also health committees } \\
\text { (with village } \\
\text { representatives) and } \\
\text { workshops with } \\
\text { government health } \\
\text { staff included a } \\
\text { qualitative assessment } \\
\text { by participants at the } \\
\text { end of each training } \\
\text { session. }\end{array}$ & $\begin{array}{l}\text { Service user: Primary } \\
\text { outcomes: neonatal } \\
\text { mortality rate (NMR); } \\
\text { maternal depression } \\
\text { scores. Secondary } \\
\text { outcomes: stillbirths; } \\
\text { maternal and perinatal } \\
\text { deaths; uptake of } \\
\text { antenatal and delivery } \\
\text { services; home care } \\
\text { practices during and } \\
\text { after delivery; health- } \\
\text { care-seeking behaviour. }\end{array}$ & $\begin{array}{l}\text { Women's groups led } \\
\text { by peer facilitators } \\
\text { reduced NMR by } \\
32 \% \text { during the } \\
3 \text { years overall and } \\
\text { by } 45 \% \text { in years } 2 \\
\text { and } 3 \text {, and moderate } \\
\text { maternal depression } \\
\text { by } 57 \% \text { in year } 3 \\
\text { (though no significant } \\
\text { effect on maternal } \\
\text { depression overall), } \\
\text { at low cost in largely } \\
\text { tribal, rural populations } \\
\text { of eastern India. }\end{array}$ & moderate \\
\hline
\end{tabular}

a'Headings in italics denote classification of outcomes in terms of 'system-level', 'service user/caregiver' level, or 'other'

'The 'Quality assessment tool for quantitative studies' by the 'Effective Public Health Practice Project' (EPHPP) [10, 11] was used for the assessment of quality and risk of bias (see also http://www.ephpp.ca/tools.html). Studies were assessed according to i) likelihood of selection bias; ii) study design; iii) whether confounders were controlled; iv) whether blinding took place; v) validity and reliability of data collection methods; vi) number of withdrawals and drop-outs; vii) intervention integrity; and viii) methods of analyses. A global quality assessment rating of 'strong', 'moderate' or 'weak' was assigned based on the responses within each of those eight categories 
Table 3 Overview of studies with quantitative and qualitative data that were included in the review

\begin{tabular}{|c|c|c|c|c|c|c|c|c|}
\hline Authors & $\begin{array}{l}\text { Countries } \\
\text { involved }\end{array}$ & Study design & $\begin{array}{l}\text { Participant group and } \\
\text { sample size }\end{array}$ & $\begin{array}{l}\text { Area and level of } \\
\text { service user } \\
\text { involvement }\end{array}$ & $\begin{array}{l}\text { Type of } \\
\text { evaluation of } \\
\text { involvement } \\
\text { (if any) }\end{array}$ & Outcomes $^{a}$ & Summary of findings & $\begin{array}{l}\text { Assessment } \\
\text { of quality }\end{array}$ \\
\hline \multirow[t]{4}{*}{$\begin{array}{l}\text { Boothby et al. } \\
\text { (2011) [14] }\end{array}$} & \multirow[t]{4}{*}{ Indonesia } & \multirow{4}{*}{$\begin{array}{l}\text { Adequacy survey of } \\
\text { decentralised mental } \\
\text { health services, and } \\
\text { outcome study of } \\
\text { effect on patients with } \\
\text { Axis I mental health } \\
\text { disorders }\end{array}$} & \multirow{4}{*}{$\begin{array}{l}\text { Patients, families, } \\
\text { community mental } \\
\text { health nurses, sub- } \\
\text { district level GPs, } \\
\text { volunteer village } \\
\text { mental health workers } \\
\text { ( } 36 \text { households, } \\
\text { number of } \\
\text { professionals not } \\
\text { specified) }\end{array}$} & \multirow{4}{*}{$\begin{array}{l}\text { Patients surveyed } \\
\text { on their perceived } \\
\text { mental health } \\
\text { pre- and post- } \\
\text { decentralisation } \\
\text { of services }\end{array}$} & \multirow[t]{4}{*}{ None } & \multirow{4}{*}{$\begin{array}{l}\text { Other (perceptions): } \\
\text { Quantitative patient and } \\
\text { carer estimations of mental } \\
\text { health and wellbeing pre- } \\
\text { \& post decentralisation; } \\
\text { qualitative staff perceptions } \\
\text { on functionality of system, } \\
\text { adequacy of system }\end{array}$} & \multirow{4}{*}{$\begin{array}{l}\text { Some progress has been made } \\
\text { towards a household-to-hospital } \\
\text { continuum of mental health care. } \\
\text { Where the system is functioning, } \\
\text { it establishes district, sub-district } \\
\text { and village levels, which effectively } \\
\text { decentralise mental health care } \\
\text { services and contribute to } \\
\text { community awareness of mental } \\
\text { health disorders. }\end{array}$} & $\begin{array}{l}\text { Quantitative } \\
\text { data: weak }\end{array}$ \\
\hline & & & & & & & & $\begin{array}{l}\text { Qualitative } \\
\text { data: }\end{array}$ \\
\hline & & & & & & & & $\begin{array}{l}\text { Criteria 1, 2, } \\
3,4,6,7,10, \\
11,12: \text { Yes }\end{array}$ \\
\hline & & & & & & & & $\begin{array}{l}\text { Criteria 5, 8, } \\
\text { 9: No }\end{array}$ \\
\hline \multirow[t]{4}{*}{$\begin{array}{l}\text { Liu et al. } \\
\text { (2007) [27] }\end{array}$} & \multirow[t]{4}{*}{ China } & \multirow{4}{*}{$\begin{array}{l}\text { Interviews and surveys } \\
\text { of managers of } 15 \text { needle } \\
\text { exchange programmes, } \\
\text { plus interviews with local } \\
\text { senior police, peer } \\
\text { educators, needles } \\
\text { exchange users and } \\
\text { patients in compulsory } \\
\text { detox }\end{array}$} & \multirow{4}{*}{$\begin{array}{l}15 \text { managers of } \\
\text { needle exchange } \\
\text { programmes, plus } \\
15 \text { local senior police, } \\
108 \text { peer educators, } \\
393 \text { needles exchange } \\
\text { users, and } 86 \text { patients } \\
\text { in compulsory detox }\end{array}$} & \multirow{4}{*}{$\begin{array}{l}\text { Peer educators } \\
\text { (majority were } \\
\text { active drug users) } \\
\text { actively involved } \\
\text { in dissemination } \\
\text { and needle } \\
\text { distribution }\end{array}$} & \multirow{4}{*}{$\begin{array}{l}\text { Effects of } \\
\text { use of peer } \\
\text { educators } \\
\text { assessed. }\end{array}$} & \multirow{4}{*}{$\begin{array}{l}\text { System-level (study) } \\
\text { (quantitative); Other } \\
\text { (attitudes) (qualitative): } \\
\text { needle turnover rate, } \\
\text { number of clients, } \\
\text { attendance, police } \\
\text { attitudes, recruitment of } \\
\text { peer educators, availability } \\
\text { of needles }\end{array}$} & \multirow{4}{*}{$\begin{array}{l}\text { Needle exchange programmes } \\
\text { are improving in terms of needle } \\
\text { turnover and attendance. Greater } \\
\text { cooperation from police, higher } \\
\text { wages for peer educators, and } \\
\text { wider awareness of the programmes } \\
\text { among drug users are needed to } \\
\text { increase coverage. Needle turnover } \\
\text { was related to peer educator wages. } \\
\text { Peer educators less likely to be } \\
\text { arrested. More peer-educators } \\
\text { needed. }\end{array}$} & $\begin{array}{l}\text { Quantitative } \\
\text { data: weak }\end{array}$ \\
\hline & & & & & & & & $\begin{array}{l}\text { Qualitative } \\
\text { data: }\end{array}$ \\
\hline & & & & & & & & $\begin{array}{l}\text { Criteria 1, 2, } \\
3,4,10,11: \\
\text { Yes }\end{array}$ \\
\hline & & & & & & & & $\begin{array}{l}\text { Criteria 5, 6, } \\
7,8,9,12 \text { : } \\
\text { No }\end{array}$ \\
\hline \multirow[t]{4}{*}{$\begin{array}{l}\text { Ndayanabangi } \\
\text { et al. (2004) } \\
\text { [32] }\end{array}$} & \multirow[t]{4}{*}{ Uganda } & \multirow{4}{*}{$\begin{array}{l}\text { Records review, key } \\
\text { informant interviews } \\
\text { and focus group } \\
\text { discussions to collect } \\
\text { data analysed by a cross- } \\
\text { section of stakeholders } \\
\text { using SWOT system to } \\
\text { validate and identify } \\
\text { strengths, weaknesses, } \\
\text { opportunities and } \\
\text { challenges. }\end{array}$} & \multirow{4}{*}{$\begin{array}{l}\text { Policy makers, health } \\
\text { providers and } \\
\text { consumers of mental } \\
\text { health services (sample } \\
\text { size not specified). }\end{array}$} & \multirow[t]{4}{*}{$\begin{array}{l}\text { Participation in } \\
\text { interviews and } \\
\text { focus groups }\end{array}$} & \multirow[t]{4}{*}{ None } & \multirow{4}{*}{$\begin{array}{l}\text { System (country)-level: } \\
\text { Quantitative and qualitative } \\
\text { data on country mental } \\
\text { health services, e.g. number } \\
\text { of mental health } \\
\text { professionals, mental health } \\
\text { funding, policies and } \\
\text { legislation, information } \\
\text { systems and research }\end{array}$} & \multirow{4}{*}{$\begin{array}{l}\text { Mental health service users are } \\
\text { rarely informed of their rights, or } \\
\text { how to access their records, and } \\
\text { rarely make complaints due to } \\
\text { ignorance of their rights. Recent } \\
\text { development of consumer } \\
\text { organisations, e.g. Mental Health } \\
\text { Uganda, Ugandan schizophrenia } \\
\text { fellowship, Association for parents } \\
\text { of children with learning } \\
\text { disabilities and Epilepsy support } \\
\text { Associations have led to some } \\
\text { increased knowledge of consumers } \\
\text { in these areas. There is a need to } \\
\text { increase advocacy for mental health } \\
\text { and develop capacity for professional } \\
\text { mental and general health workers } \\
\text { supported by appropriate policies, } \\
\text { facilities and finances. }\end{array}$} & $\begin{array}{l}\text { Quantitative } \\
\text { data: weak } \\
\text { (N/A) }\end{array}$ \\
\hline & & & & & & & & $\begin{array}{l}\text { Qualitative } \\
\text { data: }\end{array}$ \\
\hline & & & & & & & & $\begin{array}{l}\text { Criteria 1, 2, } \\
\text { 10, 11: Yes }\end{array}$ \\
\hline & & & & & & & & $\begin{array}{l}\text { Criteria } 3,4, \\
5,6,7,8,9, \\
12 \text { : No }\end{array}$ \\
\hline
\end{tabular}

'Headings in italics denote classification of outcomes in terms of 'system-level', 'service user/caregiver' level, or 'other'

${ }^{\text {b} F o r ~ q u a n t i t a t i v e ~ d a t a, ~ t h e ~ ' Q u a l i t y ~ a s s e s s m e n t ~ t o o l ~ f o r ~ q u a n t i t a t i v e ~ s t u d i e s ' ~ b y ~ t h e ~ ' E f f e c t i v e ~ P u b l i c ~ H e a l t h ~ P r a c t i c e ~ P r o j e c t ' ~(E P H P P) ~[10, ~ 11] ~ w a s ~ u s e d ~(s e e ~ a l s o ~ h t t p: / / w w w . e p h p p . c a / t o o l s . h t m l) ~(s e e ~ T a b l e ~} 2$ for further details). For qualitative data, a methodology described by Harden et al. [12] was used (see Table 4 for further details) 
Table 4 Overview of qualitative data studies included in the review

\begin{tabular}{|c|c|c|c|c|c|c|c|c|}
\hline Authors & Countries involved & Study design & $\begin{array}{l}\text { Participant } \\
\text { group and } \\
\text { sample size }\end{array}$ & $\begin{array}{l}\text { Area and level } \\
\text { of service user } \\
\text { involvement }\end{array}$ & $\begin{array}{l}\text { Type of evaluation } \\
\text { of involvement } \\
\text { (if any) } \\
\end{array}$ & Outcomes $^{a}$ & $\begin{array}{l}\text { Summary of } \\
\text { findings }\end{array}$ & $\begin{array}{l}\text { Assessment } \\
\text { of quality }\end{array}$ \\
\hline \multirow{2}{*}{$\begin{array}{l}\text { Camatta et } \\
\text { al. (2011) } \\
\text { [20] }\end{array}$} & \multirow[t]{2}{*}{ Brazil } & \multirow{2}{*}{$\begin{array}{l}\text { Qualitative } \\
\text { evaluation of secondary } \\
\text { mental health } \\
\text { service (in-depth } \\
\text { interviews) }\end{array}$} & \multirow{2}{*}{$\begin{array}{l}13 \text { family members } \\
\text { of secondary mental } \\
\text { health services }\end{array}$} & \multirow{2}{*}{$\begin{array}{l}\text { Evaluation of } \\
\text { mental health } \\
\text { services }\end{array}$} & \multirow{2}{*}{$\begin{array}{l}\text { Qualitative } \\
\text { evaluation of } \\
\text { services (rather } \\
\text { than of service } \\
\text { user involvement) } \\
\text { using in-depth } \\
\text { interviews. Data } \\
\text { were validated in } \\
\text { a follow-up work } \\
\text { shop with } \\
\text { participants }\end{array}$} & \multirow[b]{2}{*}{$\begin{array}{l}\text { Other (perceptions/ } \\
\text { satisfaction): Interview } \\
\text { data were } \\
\text { categorised into } \\
\text { predefined } \\
\text { categories based } \\
\text { on both internal } \\
\text { and external } \\
\text { dimensions of the } \\
\text { service. Internal } \\
\text { factors included: } \\
\text { ambiance, } \\
\text { characteristics of } \\
\text { the provider team, } \\
\text { therapeutic activities } \\
\text { and family } \\
\text { involvement. } \\
\text { External factors } \\
\text { included: Public } \\
\text { policies (including } \\
\text { provision and } \\
\text { availability of mental } \\
\text { health professionals } \\
\text { and treatments), and } \\
\text { the relationship } \\
\text { between society } \\
\text { and mental illness } \\
\text { (including better } \\
\text { integration of the } \\
\text { CAPS service in the } \\
\text { community and } \\
\text { everyday life). }\end{array}$} & \multirow{2}{*}{$\begin{array}{l}\text { The article } \\
\text { concludes that it is } \\
\text { important to give } \\
\text { families a voice and } \\
\text { to facilitate their } \\
\text { collaboration in } \\
\text { mental health care } \\
\text { and system reform. }\end{array}$} & $\begin{array}{l}\text { Criteria 1, 4, 5, } \\
6,10,11 \text { : Yes }\end{array}$ \\
\hline & & & & & & & & $\begin{array}{l}\text { Criteria 2, 3, 7, } \\
\text { 8, 9, 12: No }\end{array}$ \\
\hline \multirow[t]{2}{*}{$\begin{array}{l}\text { Cohen et al. } \\
\text { (2012) [25] }\end{array}$} & \multirow[t]{2}{*}{ Ghana } & \multirow[t]{2}{*}{ Qualitative } & \multirow{2}{*}{$\begin{array}{l}18 \text { self-help groups } \\
\text { (SHGs), } 5 \text { NGOs, com- } \\
\text { munity mental health } \\
\text { nurses, health service } \\
\text { administrators }\end{array}$} & \multirow[t]{2}{*}{$\begin{array}{l}\text { Interviews with } \\
\text { these groups/ } \\
\text { staff }\end{array}$} & \multirow[t]{2}{*}{ None } & \multirow{2}{*}{$\begin{array}{l}\text { Service user/ } \\
\text { caregiver: } \\
\text { Clinical, social and } \\
\text { economic outcomes, } \\
\text { e.g. reasons for } \\
\text { joining groups, } \\
\text { perceived } \\
\text { benefits of } \\
\text { membership } \\
\text { in groups, social } \\
\text { inclusion, social and } \\
\text { financial support, } \\
\text { biomedical } \\
\text { treatments }\end{array}$} & \multirow{2}{*}{$\begin{array}{l}\text { SHGs have the } \\
\text { potential } \\
\text { to serve as key } \\
\text { components of } \\
\text { community mental } \\
\text { health programmes } \\
\text { in low-resource } \\
\text { settings. The } \\
\text { strongest evidence } \\
\text { concerns how SHGs } \\
\text { provide a range of } \\
\text { supports, e.g. social, } \\
\text { financial, and } \\
\text { practical, to service } \\
\text { users and caregivers. } \\
\text { The groups also }\end{array}$} & $\begin{array}{l}\text { Criteria 1, 2, 3, } \\
4,10,11,12 \text { : } \\
\text { Yes }\end{array}$ \\
\hline & & & & & & & & $\begin{array}{l}\text { Criteria 5, 6, 7, } \\
\text { 8, 9: No }\end{array}$ \\
\hline
\end{tabular}


Table 4 Overview of qualitative data studies included in the review (Continued)

\begin{tabular}{|c|c|c|c|c|c|c|c|c|}
\hline & & & & & & & $\begin{array}{l}\text { appear to foster } \\
\text { greater acceptance } \\
\text { of service users by } \\
\text { their families and } \\
\text { by communities at } \\
\text { large. Membership } \\
\text { in SHGs appears to } \\
\text { be associated with } \\
\text { more consistent } \\
\text { treatment and } \\
\text { better outcomes for } \\
\text { those who are ill. }\end{array}$ & \\
\hline \multirow[t]{2}{*}{$\begin{array}{l}\text { Crabtree } \\
\text { (2005) [15] }\end{array}$} & \multirow[t]{2}{*}{ Malaysia (UM) } & \multirow[b]{2}{*}{$\begin{array}{l}\text { Ethnographic } \\
\text { qualitative } \\
\text { methods, in-depth } \\
\text { interviews with } \\
\text { numerous inpatients } \\
\text { using 'opportunistic } \\
\text { sampling'. Staff } \\
\text { accounts for insights } \\
\text { into the 'culture' of } \\
\text { hospital setting. Also, } \\
\text { critical observation } \\
\text { and hospital records } \\
\text { over } 18 \text { months. }\end{array}$} & \multirow{2}{*}{$\begin{array}{l}\text { Psychiatric service } \\
\text { users, staff (sample } \\
\text { size not mentioned) }\end{array}$} & \multirow[t]{2}{*}{$\begin{array}{l}\text { Interviews with } \\
\text { service users }\end{array}$} & \multirow[t]{2}{*}{ None } & \multirow{2}{*}{$\begin{array}{l}\text { Other (attitudes): } \\
\text { Staff attitudes } \\
\text { towards patient } \\
\text { 'compliance' and } \\
\text { resistance to } \\
\text { treatment; healing } \\
\text { and spirituality }\end{array}$} & \multirow[b]{2}{*}{$\begin{array}{l}\text { Undisputed power } \\
\text { of the medical } \\
\text { profession in } \\
\text { Malaysia has led to } \\
\text { a lack of evolved } \\
\text { 'service-user' } \\
\text { perspective. Few } \\
\text { patient rights are } \\
\text { recognised, } \\
\text { especially } \\
\text { non-treatment. } \\
\text { Paternalistic and } \\
\text { custodial attitude } \\
\text { does not acknow } \\
\text { ledge issues of } \\
\text { spirituality/alternative } \\
\text { healing practices } \\
\text { important to } \\
\text { hospitalised patients. } \\
\text { Modernisation of } \\
\text { services did not lead } \\
\text { to parallel } \\
\text { development of } \\
\text { patient participation/ } \\
\text { cultural responses. }\end{array}$} & $\begin{array}{l}\text { Criteria 2, 4, } \\
\text { 10, 11: Yes }\end{array}$ \\
\hline & & & & & & & & $\begin{array}{l}\text { Criteria 1,3,5, } \\
6,7,8,9,12 \text { : } \\
\text { No }\end{array}$ \\
\hline \multirow{2}{*}{$\begin{array}{l}\text { De La } \\
\text { Espriella \& } \\
\text { Caycedo } \\
\text { Bustos } \\
\text { (2013) [18] }\end{array}$} & \multirow[t]{2}{*}{ Colombia } & \multirow{2}{*}{$\begin{array}{l}\text { Literature/policy } \\
\text { document review } \\
\text { and qualitative focus } \\
\text { groups and } \\
\text { consultation meetings }\end{array}$} & \multirow{2}{*}{$\begin{array}{l}40 \text { service users, } 40 \\
\text { family members and } \\
33 \text { health care } \\
\text { professionals }\end{array}$} & \multirow{2}{*}{$\begin{array}{l}\text { Service user } \\
\text { involvement in } \\
\text { development of } \\
\text { policy/strategy; } \\
\text { declaration of } \\
\text { mental health } \\
\text { patient's duties and } \\
\text { rights }\end{array}$} & \multirow[t]{2}{*}{ None } & \multirow{2}{*}{$\begin{array}{l}\text { System (study: } \\
\text { development of } \\
\text { policy): Qualitative } \\
\text { data and document } \\
\text { review to develop } \\
\text { an institutional } \\
\text { policy/declaration } \\
\text { of mental health } \\
\text { patients' duties } \\
\text { and rights (incl. user } \\
\text { participation) }\end{array}$} & \multirow{2}{*}{$\begin{array}{l}\text { Ten rights/policies } \\
\text { were developed/ } \\
\text { adapted through } \\
\text { consultation } \\
\text { with service users } \\
\text { and families, which } \\
\text { ensured } \\
\text { comprehensibility, } \\
\text { clarity of terms, } \\
\text { understanding and } \\
\text { sufficient } \\
\text { information. }\end{array}$} & $\begin{array}{l}\text { Criteria 1, 2, 4, } \\
5,10,11,12 \text { : } \\
\text { Yes }\end{array}$ \\
\hline & & & & & & & & $\begin{array}{l}\text { Criteria 3, 6, 7, } \\
\text { 8, 9: No }\end{array}$ \\
\hline
\end{tabular}


Table 4 Overview of qualitative data studies included in the review (Continued)

\begin{tabular}{|c|c|c|c|c|c|c|c|c|}
\hline $\begin{array}{l}\text { Kleintjes et } \\
\text { al. (2013) } \\
\text { [28] }\end{array}$ & $\begin{array}{l}\text { Ghana, Kenya, } \\
\text { Rwanda, South } \\
\text { Africa, Tanzania, } \\
\text { Uganda, Zambia }\end{array}$ & $\begin{array}{l}\text { Semi-structured key } \\
\text { informant interviews } \\
\text { with leaders of mental } \\
\text { health self-help } \\
\text { organisations, plus } \\
\text { documentary review }\end{array}$ & $\begin{array}{l}11 \text { ( } 4 \text { women, } 7 \text { men) } \\
\text { leaders of } 9 \text { self-help } \\
\text { organisations for ser- } \\
\text { vice users and carers }\end{array}$ & $\begin{array}{l}\text { Leaders of self-help } \\
\text { organisations inter- } \\
\text { viewed about their } \\
\text { experience in the } \\
\text { organisations; inter- } \\
\text { view schedule was } \\
\text { refined based on } \\
\text { feedback from user } \\
\text { advocates (and } \\
\text { public sector men- } \\
\text { tal health } \\
\text { practitioners) }\end{array}$ & None & $\begin{array}{l}\text { Other (study): } \\
\text { Establishment and } \\
\text { sustainability of } \\
\text { mental health } \\
\text { self-help organisa } \\
\text { tions, e.g. leadership, } \\
\text { membership, staffing, } \\
\text { advocacy, vision and } \\
\text { objectives of } \\
\text { organisation }\end{array}$ & $\begin{array}{l}\text { Authors concluded } \\
\text { that self-help } \\
\text { organisations } \\
\text { can provide crucial } \\
\text { support to service } \\
\text { users' recovery in } \\
\text { resource-poor } \\
\text { settings in Africa. } \\
\text { Support of other } \\
\text { agencies can } \\
\text { assist to build } \\
\text { organisations' } \\
\text { capacity for sustain } \\
\text { able support to } \\
\text { members' recovery. }\end{array}$ & $\begin{array}{l}\text { Criteria 1, 2,3, } \\
4,5,6,7,9, \\
\text { 10, 11, 12: Yes } \\
\text { Criteria 8: No }\end{array}$ \\
\hline $\begin{array}{l}\text { Nesnanov \& } \\
\text { Vasilyeva } \\
\text { (2013) [31] }\end{array}$ & Russia & $\begin{array}{l}\text { Survey by the Russian } \\
\text { Psychiatric Association }\end{array}$ & $\begin{array}{l}\text { Mental health } \\
\text { professionals and } \\
\text { consumers (sample } \\
\text { size not mentioned) }\end{array}$ & $\begin{array}{l}\text { Participation in } \\
\text { survey }\end{array}$ & None & $\begin{array}{l}\text { Other (satisfaction): } \\
\text { Qualitative } \\
\text { satisfaction } \\
\text { data (on mental } \\
\text { health care system) }\end{array}$ & $\begin{array}{l}\text { Majority of } \\
\text { professionals } \\
\text { and mental health } \\
\text { consumers not } \\
\text { satisfied with } \\
\text { mental health care } \\
\text { system in Russia } \\
\text { today. Suggestions } \\
\text { made to improve } \\
\text { services and } \\
\text { challenge stigma. }\end{array}$ & $\begin{array}{l}\text { N/A (as } \\
\text { congress } \\
\text { abstract) }\end{array}$ \\
\hline $\begin{array}{l}\text { Petersen et } \\
\text { al. (2012) } \\
{[24]}\end{array}$ & South Africa & $\begin{array}{l}\text { Participatory } \\
\text { implementation } \\
\text { framework for } \\
\text { development of } \\
\text { mental health } \\
\text { services for common } \\
\text { mental disorders } \\
\text { (CMDs) in a rural } \\
\text { sub-district in South } \\
\text { Africa as a case study. } \\
\text { Qualitative process } \\
\text { evaluation by } \\
\text { interviewing service } \\
\text { providers and users. }\end{array}$ & $\begin{array}{l}\text { Service providers } \\
\text { and users ( } 4 \text { focus } \\
\text { groups with } 15 \\
\text { community mental } \\
\text { health workers); } 2 \\
\text { interviews with } \\
\text { psychosocial group } \\
\text { facilitators and } 9 \\
\text { participants, } 29 \\
\text { community members, } \\
9 \text { representatives from } \\
\text { mental health services } \\
\text { plus } 2 \text { community } \\
\text { representatives }\end{array}$ & $\begin{array}{l}\text { Participation in } \\
\text { interviews }\end{array}$ & $\begin{array}{l}\text { Involving community } \\
\text { members in the } \\
\text { development and } \\
\text { delivery of psychosocial } \\
\text { interventions for } \\
\text { women with depression } \\
\text { illustrated potential } \\
\text { usefulness of community } \\
\text { consultation in promoting } \\
\text { cultural congruence. } \\
\text { Community members well } \\
\text { placed to provide local } \\
\text { knowledge on } \\
\text { interventions to mediate } \\
\text { pathways to health and } \\
\text { how to manage } \\
\text { problems within the } \\
\text { constraints of their } \\
\text { cultural and material } \\
\text { realities. Social support } \\
\text { afforded by participation } \\
\text { in groups can enhance } \\
\text { participants' individual } \\
\text { coping capacities and }\end{array}$ & $\begin{array}{l}\text { System, service user/ } \\
\text { caregiver and other: } \\
\text { Qualitative: 1) } \\
\text { benefits and 2) } \\
\text { challenges of } \\
\text { community } \\
\text { participation }\end{array}$ & $\begin{array}{l}\text { In addition to } \\
\text { contributing to } \\
\text { scaling up mental } \\
\text { health services, } \\
\text { community } \\
\text { participation } \\
\text { can potentially } \\
\text { promote } \\
\text { development of } \\
\text { culturally } \\
\text { competent mental } \\
\text { health services and } \\
\text { greater community } \\
\text { control of mental } \\
\text { health. }\end{array}$ & $\begin{array}{l}\text { Criteria 1, 2, 3, } \\
4,5,6,8,9, \\
\text { 10, 11, 12: Yes } \\
\text { Criteria 7: No }\end{array}$ \\
\hline
\end{tabular}


Table 4 Overview of qualitative data studies included in the review (Continued)

\begin{tabular}{|c|c|c|c|c|c|c|c|c|}
\hline \multirow[t]{2}{*}{$\begin{array}{l}\text { Schilder et } \\
\text { al. (2004) } \\
\text { [29] }\end{array}$} & \multirow{2}{*}{$\begin{array}{l}\text { Bulgaria (plus } \\
\text { exploratory } \\
\text { studies in India } \\
\text { and Zambia) }\end{array}$} & \multirow{2}{*}{$\begin{array}{l}\text { Field tests of focus } \\
\text { group methodology } \\
\text { in India and Zambia } \\
\text { with final field test } \\
\text { in Bulgaria. }\end{array}$} & \multirow{2}{*}{$\begin{array}{l}\text { Consumers, family } \\
\text { members, NGOs, } \\
\text { professionals and } \\
\text { government } \\
\text { representatives (in } \\
\text { Bulgaria: } 15 \text { service } \\
\text { user, } 6 \text { carers, } 5 \text { mental } \\
\text { health administrators, } \\
11 \text { medical students) }\end{array}$} & \multirow[t]{2}{*}{$\begin{array}{l}\text { Participation in } \\
\text { focus groups }\end{array}$} & \multirow[t]{2}{*}{$\begin{array}{l}\text { Relatives seemed the } \\
\text { most initially eager but } \\
\text { dropped out the most. }\end{array}$} & \multirow{2}{*}{$\begin{array}{l}\text { Other (study): Use } \\
\text { and appropriateness } \\
\text { of focus group } \\
\text { methodology }\end{array}$} & \multirow[b]{2}{*}{$\begin{array}{l}\text { Use of focus groups } \\
\text { proved appropriate } \\
\text { in helping to clarify } \\
\text { issues that could } \\
\text { help substantiate } \\
\text { data collection and } \\
\text { comparison across } \\
\text { different cultures } \\
\text { and regions. A } \\
\text { number of } \\
\text { instrument } \\
\text { questions were } \\
\text { developed further } \\
\text { based on the } \\
\text { exploratory focus } \\
\text { group work. }\end{array}$} & $\begin{array}{l}\text { Criteria 1, 3, } 4 \\
6,7,10,11, \\
12: \text { Yes }\end{array}$ \\
\hline & & & & & & & & $\begin{array}{l}\text { Criteria 2, 5, } 8 \text {, } \\
\text { 9: No }\end{array}$ \\
\hline
\end{tabular}

personal empowerment

previous

supporting previous

${ }^{2}$ Headings in italics denote classification of outcomes in terms of 'system-level', 'service user/caregiver' level, or 'other'

${ }^{\text {b} T w e l v e ~ r e v i e w ~ c r i t e r i a ~ w e r e ~ u s e d ~ t o ~ a s s e s s ~ t h e ~ q u a l i t y ~ o f ~ q u a l i t a t i v e ~ s t u d i e s . ~ T h e s e ~ w e ~}$ were as follows: 1 . Were the aims and objectives clearly reported? 2. Was there an adequate description of the context in which the research was carried out? 3. Was there an adequate description of the sample and the methods by which the sample was identified and recruited? 4. Was there an adequate description of the methods used to collect data? 5 . Was there an adequate description of the methods used to analyse data? 6. Were there attempts to establish the reliability of the data collection tools (for example, by use of interview topic guides)? 7 . Were there attempts to establish the validity of the data collection tools (for example, with pilot interviews)? 8. Were there attempts to establish the reliability of the data analysis methods (for example, by use of independent coders)? 9 . Were there attempts to establish the validity of data analysis

methods (for example, by searching for negative cases)? 10. Did the study use appropriate data collection methods for helping people to express their views? 11. Did the study use appropriate methods for ensuring the data analysis was grounded in the views of people? 12. Did the study actively involve relevant groups in its design and conduct? 
Table 5 Overview of descriptive non-data-based studies included in the review

\begin{tabular}{|c|c|c|c|c|c|c|}
\hline Authors & Countries involved & Study design & $\begin{array}{l}\text { Participant } \\
\text { group and } \\
\text { sample size }\end{array}$ & $\begin{array}{l}\text { Area and level of } \\
\text { service user } \\
\text { involvement }\end{array}$ & $\begin{array}{l}\text { Type of evaluation of } \\
\text { involvement (if any) }\end{array}$ & $\begin{array}{l}\text { Type of data } \\
\text { collected/ } \\
\text { outcomes }\end{array}$ \\
\hline Agrest (2011) [17] & $\begin{array}{l}\text { Argentina (though } \\
\text { also discusses } \\
\text { historical involvement } \\
\text { of service users in } \\
\text { other counties } \\
\text { (mainly England, } \\
\text { Australia, Canada)) }\end{array}$ & $\begin{array}{l}\text { Commentary, non-data } \\
\text { based paper (opinion/ } \\
\text { commentary on the } \\
\text { history and future of } \\
\text { service user groups, } \\
\text { especially in relation to } \\
\text { Argentina and specifically } \\
\text { Buenos Aires) }\end{array}$ & N/A & $\begin{array}{l}\text { There are a range of } \\
\text { types of organisations } \\
\text { and actors in Buenos } \\
\text { Aires related to the } \\
\text { service user movement } \\
\text { including those related } \\
\text { to families/carers, } \\
\text { survivors, those attached } \\
\text { to human rights, service } \\
\text { users only, and also } \\
\text { mixed associations with } \\
\text { service users, families } \\
\text { and psychiatrists. A new } \\
\text { movement 'nothing } \\
\text { about us without us' by } \\
\text { and for service users is } \\
\text { growing and importantly } \\
\text { promotes activities in } \\
\text { the community. }\end{array}$ & N/A & $\mathrm{N} / \mathrm{A}$ \\
\hline Ardila (2011) [19] & Argentina & $\begin{array}{l}\text { No study design: This } \\
\text { paper provides a } \\
\text { commentary and } \\
\text { develops some ideas } \\
\text { related to involving } \\
\text { users in service } \\
\text { improvement }\end{array}$ & N/A & $\mathrm{N} / \mathrm{A}$ & N/A & N/A \\
\hline $\begin{array}{l}\text { Furtado \& Campos } \\
\text { (2008) [21] }\end{array}$ & Brazil & $\begin{array}{l}\text { Commentary reflection } \\
\text { on previous evaluation } \\
\text { of mental health service, } \\
\text { non-data based paper }\end{array}$ & N/A & $\begin{array}{l}\text { Upon reflection, the } \\
\text { participation of service } \\
\text { users in the service } \\
\text { evaluation was } \\
\text { described as 'gradual'. } \\
\text { Researchers were } \\
\text { exclusively involved at } \\
\text { the start of the project } \\
\text { because of funding and } \\
\text { time constraints; } \\
\text { however, other groups } \\
\text { became involved later in } \\
\text { the analysis of results, } \\
\text { and final workshops and } \\
\text { dissemination. }\end{array}$ & $\begin{array}{l}\text { Makes } \\
\text { recommendations } \\
\text { about what factors } \\
\text { to consider in the } \\
\text { participatory } \\
\text { evaluation of mental } \\
\text { health services. }\end{array}$ & $\mathrm{N} / \mathrm{A}$ \\
\hline $\begin{array}{l}\text { Hayward \& Cutler } \\
\text { (2007) [16] }\end{array}$ & Romania & $\begin{array}{l}\text { Describes the progress } \\
\text { and achievements of } \\
\text { grassroots organisations } \\
\text { and people with mental } \\
\text { health problems in } \\
\text { Romania in developing } \\
\text { policies to promote } \\
\text { community-based } \\
\text { mental health services at } \\
\text { the national level. }\end{array}$ & N/A & $\begin{array}{l}\text { Stakeholders from all } \\
\text { over Romania had the } \\
\text { opportunity to work } \\
\text { together, network and } \\
\text { create strategic } \\
\text { relationships for change } \\
\text { by building grassroots } \\
\text { coalitions across } \\
\text { Romania }\end{array}$ & $\begin{array}{l}\text { This has had some } \\
\text { impact on policy- } \\
\text { makers and } \\
\text { subsequent actions }\end{array}$ & $\mathrm{N} / \mathrm{A}$ \\
\hline
\end{tabular}

$[18,28,29])$ contained study outcomes that were intended to be improved through service user participation (outcomes included, for instance, needle turnover rates, factors around the sustainability of mental health organisations, development of a scale, establishment of a mental health policy). For six of the studies, the primary outcomes related to satisfaction data or data on perceptions or attitudes (one quantitative [30] and four qualitative studies $[15,20,27,31]$, plus one with both types of data [14]). A further two studies [13, 32] included outcomes at the country level (such as access to medications, number of mental health staff, policies). Four studies did not include any outcomes, as they were non-data-based and descriptive (see Table 5).

In the non-peer-reviewed grey literature, in addition to various websites by service user groups or organisations working with service users or caregivers, five relevant reports were identified, as well as one self-advocacy 


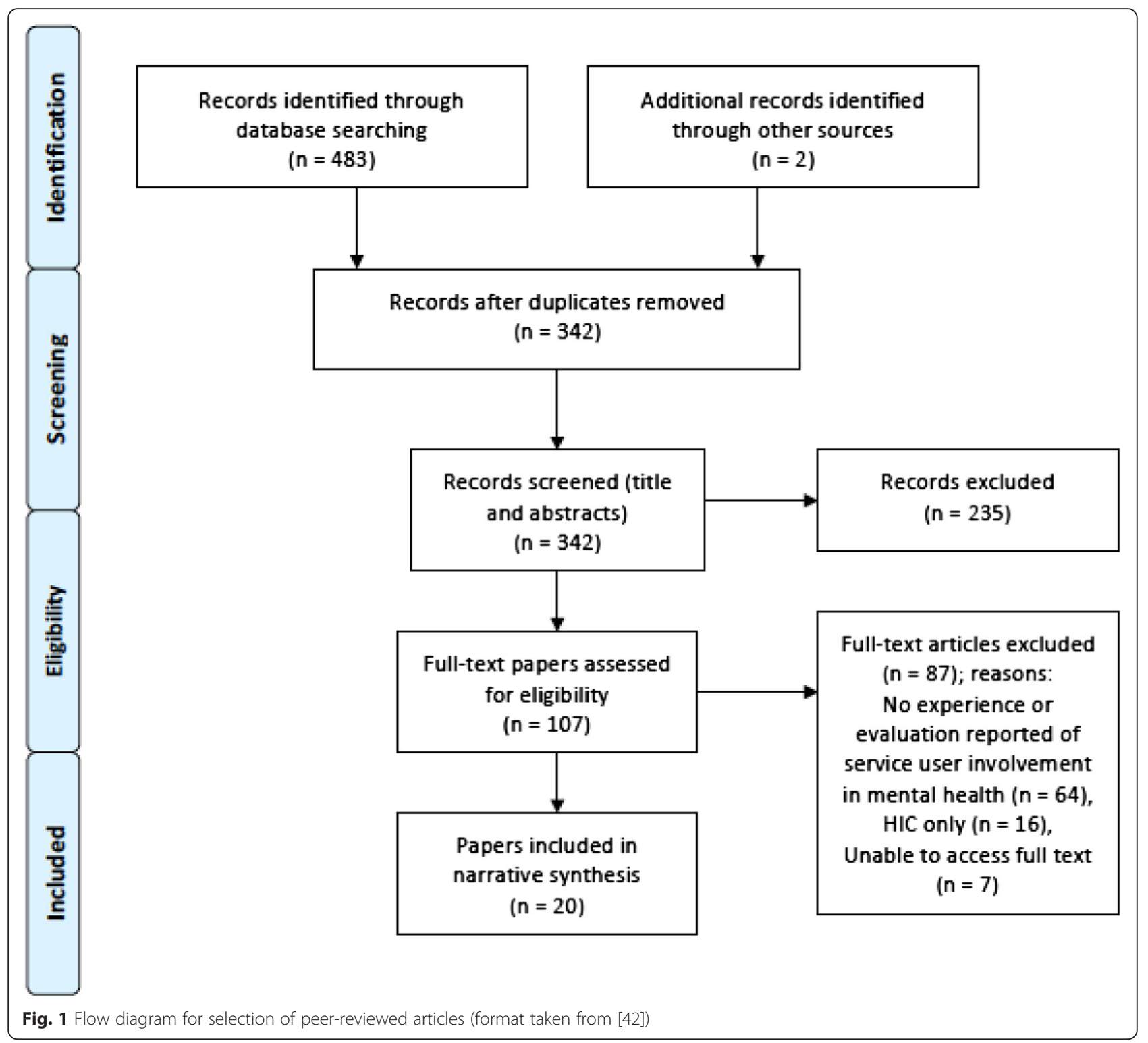

toolkit, and one newsletter. From these seven sources, information was included from eight low-income countries (Indonesia, Kenya, Lao PDR, Malawi, Nepal, Rwanda, Tanzania, Uganda), three lower middle-income countries (Ghana, India, Sri Lanka), and one upper middle-income country (South Africa), at the time of publication. Two reports were produced after 2010, four between 2005 and 2010, and one before 2000.

\section{Quality assessment of papers}

The majority of included papers $(n=8)$ were qualitative or non-data-based studies $(n=4)$. Five studies presented quantitative data only, with a further three studies including both quantitative and qualitative data. The quality assessment of papers is shown in Tables 2, 3 and 4 for individual studies. Overall, the quality of papers that were included in the review was weak. For studies that included quantitative data, the quality was categorised as weak for all but one paper, for which the quality was categorised to be moderate (the cluster-RCT, which involved peer-facilitated women's groups, and therefore was one of the papers that was included in the review under the secondary criteria). For papers that included qualitative data, no papers fulfilled all twelve quality assessment criteria, though two papers fulfilled eleven of the criteria. The average number of criteria that were fulfilled was 7.3 (ranging between 4 and 11).

\section{Findings of peer-reviewed studies}

Overall, the studies that were identified in this review provided a weak evidence base for service user and caregiver involvement in mental health system strengthening 
in LMICs. Many were of low quality (see above) and just four studies included an explicit evaluative element of service user/caregiver involvement. Most of the literature reported about service user and caregiver involvement at the service-level rather than the systems-level, and commonly involved service users as research participants for the evaluation of services rather than their direct participation in the development of policies or services, the training of health workers in mental health care, or within mental health research. There were also few reports that evaluated service user involvement. The level of service user involvement reported in the literature varied considerably across countries. However, there were a few favourable studies that provided some indication as to research areas that could be pursued further, in particular about the development of policies and strategies, including advocacy work, and to a lesser extent the development of services, service monitoring and evaluation.

\section{Development of policies or strategies}

The main evidence from the peer-reviewed literature in regards to the development of policies or strategies reported on the usefulness and feasibility of consultation processes with service user involvement, and showed that these processes may lead to an improvement in mental health services and/or outcomes. A study that used data from the World Health Organization Assessment Instrument for Mental Health Systems (WHO-AIMS) from 63 countries, for example, showed that participation of familybased organisations in the development of mental health legislation increased availability of psychotropic medication in countries by $17 \%$ [13]. Another paper provided a descriptive account of a consultation process in Colombia with representatives of patients, families, medical students and mental health workers to derive a declaration of mental health patients' duties and rights [18]. One challenge that has been reported is that people in power may not be willing to give up control, which may result in the exclusion of service users [16]. To address this imbalance in power relations, grassroots public action has been suggested. Hayward \& Cutler [16], for instance, described the coalitions between grassroots organisations and people with mental health problems in Romania to develop policies to promote community-based services.

A qualitative study by Ndyanabangi et al. [32] that involved interviews and focus groups with service users, policy makers and health providers in Uganda highlighted the importance, usefulness and feasibility of capacitybuilding activities for service users and caregivers in advocacy skills. The study established that service users were rarely informed of their rights, so hardly ever made complaints, but that the recent increase in service user organisations had led to an enhanced knowledge base for service users in their rights overall. Similarly, a study in Argentina and Chile found that with structured support, people with intellectual disability (ID) were able to exercise their rights to a level comparable to peers without ID [26]. This may be relevant to policy development in that if service users are not aware or do not have information about their rights, their contribution to policy development is likely to be limited or altogether absent.

\section{Planning or development of services}

There was very little evidence in the peer-reviewed literature on how best to involve service users and caregivers in the planning or development of services. The best research identified was from a case study on the involvement of community members in the development and delivery of psychosocial interventions for women with depression in South Africa. Through a participatory implementation framework, the service users and service providers were actively involved in the development of the interventions (through in-depth focus groups and consultations), such as a peer facilitated group intervention based on the principles of interpersonal therapy for people with depression [24].

\section{Service monitoring and evaluation}

The review identified several peer-reviewed papers that involved service users and/or caregivers in the evaluation of mental health services, for example using satisfaction data [14, 20, 31, 33], though few of these included either an evaluation of service user involvement or service user involvement in the monitoring of services themselves. That is, service users or caregivers did not participate in the process of assessing satisfaction levels (monitoring) or devising appropriate responses (service development). However, a useful methodological framework for the evaluation of mental health services was presented in a commentary on the evaluation of mental health services in Brazil, where the participation of service users in the service appraisal was 'gradual'. That is, researchers were exclusively involved at the start of the project (due to funding and time constraints), but then other stakeholders participated later in the analysis of results, and the final workshops and dissemination [21]. The framework proposed a synthesis of perspectives and recommended five dimensions that should be considered in the participatory evaluation process.

\section{Mental health research}

The review produced no evidence on how best to involve service users or caregivers within mental health research in LMICs. 


\section{Training health workers in mental health care}

The review produced no evidence or reports on service user or caregiver involvement in the training of health workers in mental health care in LMICs.

\section{Service delivery and support groups}

The review showed that there is some evidence for the benefits of service user or caregiver involvement in service delivery and/or support groups. This has included involvement of peer educators in needle exchange programmes for alcohol and drug abuse in China [27]; the employment of service users' family members as case managers for people with schizophrenia in Iran when compared to psychology graduates [22]; service user and carer self-help groups in several African countries [28], such as Ghana [25]; as well as women's groups led by peer facilitators to reduce moderate maternal depression in India [23].

\section{Discussion}

\section{Summary of evidence}

Overall, this systematic review showed that although there were signs of service user and caregiver involvement in mental health system strengthening in numerous (about 26) countries, there was a lack of high-quality research and a weak evidence base for the work that was being conducted across countries (up to the end of 2013). Most of the literature reported service user and caregiver involvement at the service-level (for example, in regards to the delivery of services such as self-help and support groups) rather than the systems-level (such as at the policy, planning, monitoring or evaluation level), and commonly involved service users as research participants in the evaluation of services (for example, surveying their satisfaction with services) rather than in the direct development of policies or services, the training of health workers in mental health care, or within mental health research. Indeed, no evidence at all was found for the latter two issues, and therefore underlined the substantial gap in the literature in these areas. There were also few reports that evaluated service user involvement. Furthermore, outcomes were often vague in terms of their link to service user involvement; many of the outcomes measured related to perceptions, attitudes or satisfaction data with no clear and direct relation to the impact of service user involvement on mental health system strengthening, particularly in relation to (i) the effects of service user or caregiver involvement on service users or caregivers themselves, or (ii) the impact of their involvement on services.

One reason for these findings may be that most of the service user organisations are still few and fragmented, and that it is difficult to document some of their best practices. However, there were some encouraging studies on the development of policies and strategies, including advocacy work, and to a lesser extent the development of services, service monitoring and evaluation, with some indication to areas that could be pursued in the future.

The review showed overall that service user and caregiver involvement in mental health system strengthening is possible, and there are tentative signs that their direct involvement may lead to improvements in mental health services and outcomes. Generally, research on service user or caregiver involvement in mental health system strengthening seems to be on the rise, as most research has been published in the last ten years. On the other hand, whilst there seem to be good intentions in some countries, these are often not translated into practice. For example, in Argentina, even though there has been an increase in service user involvement over the last twenty years, this has not yet been translated into substantial changes in services or an improvement in service users' inclusion and quality of life [17]. It was also clear from the literature review that service user and caregiver involvement varied significantly across countries. For instance, whilst in Uganda, quite a large presence of service user advocacy groups is described in the grey literature $[8,34-36]$, other countries, such as Malaysia, have reported a lack of evolved service user perspectives [15]. Since there are a few countries that have greater awareness in this area than others, it will therefore be important for models of best practice to be shared across countries and regions.

Table 6 provides an overview of recommendations for future studies on service user or caregiver involvement in mental health system strengthening. One important recommendation is for further research to incorporate rigorous evaluative elements of service user and caregiver involvement. This could include high-quality studies such as RCTs, as well as participatory approaches. Case studies that capture the complexity of the impact of service user and caregiver involvement may also yield more revealing insights. Without an evaluation of interventions, the allocation of scarce resources becomes difficult, given the potential for harm (for example, due to stigma), so it is important not to assume that every intervention is beneficial. Future research needs to clarify which interventions are valuable, and also acceptable within different socio-cultural contexts, and which are less so.

\section{Grey literature}

A search of the grey literature identified several reports of encouraging projects and groups that incorporated participation by service users, their families or caregivers across several countries, particularly in relation to advocacy and empowerment work. A growing number of organisations (in particular non-governmental organisations 
Table 6 Recommendations for future studies on service user and caregiver involvement in mental health system strengthening

- More high-quality research is needed that directly relates to the systems level (rather than the service-level), specifically to address the gap in evidence on service user and caregiver involvement in the development of policies and strategies, the planning and development of services, the training of health workers in mental health care, and within mental health research.

- More systematic evaluation needs to be incorporated into studies of service user and caregiver involvement, including rigorous study designs with low risk of bias, such as RCTs complemented by participatory approaches or case studies.

- Outcome evaluations need to be more clearly defined in terms of their relationship to service user or caregiver involvement. Specifically, more studies need to measure the effects of service user or caregiver involvement on either service users or caregivers themselves (e.g. mental health status, well-being, uptake of services, caregiver burden), or the impact of their involvement on services (e.g. availability, accessibility and appropriateness of mental health services, pathways to and through care).

- Stakeholder involvement (including service users and caregivers) in study design is recommended that may offer a solution to the slow translation of the findings into meaningful changes in practice at the service or systems level.

- Research needs to take into account the local context, culture, traditions and values in the implementation of interventions or capacitybuilding activities.

- Research needs to draw on resources that are available within study countries, e.g. engage and involve policy makers, decision-makers, advocacy or service user groups. Interventions in which there is no or very limited service user involvement may need to focus initially on empowerment or the establishment of new service user groups.

- Service users and caregivers need to be fully informed of the reasons for the studies in which they participate and give informed consent to do so. Research could be used as a platform to provide information to service users and caregivers about their rights, and to foster advocacy work. - Models of best practice need to be shared widely and across countries. One way in which to do this may be to empower service user organisations to deliver those services that they are best at, and to then facilitate the documentation of these practices.

(NGOs)) across various low- and middle-income countries advocate for service users' rights and needs, with the recognition that not all service users and families may be interested in roles of activism. These include, for example, Action for Mental Illness (ACMI) in India (see http:// mhinnovation.net/organisations/action-mental-illnessindia-acmi), who campaign for service user involvement at the social level (for example, running empowerment and advocacy programs for family carers and service users); political level (such as lobbying and negotiating); the legal (state) level; and media level (including civil society and publications). Others include the World Network of Users and Survivors (WNUSP) Working Group (see http:// www.wnusp.net/), which was established in 2013 and is a global forum to promote the rights and interests of service users; the Pan-African Network of People with Psychosocial Disabilities (PANUSP) [8] (also see http://www.panusp.org/), which was established in Uganda in 2005 and now extends to nine African countries; and the NGO BasicNeeds, which was founded in 1999 and now has programmes (including empowerment and self-help groups) in at least eight countries across Africa and Asia [37]. A useful toolkit has been developed by BasicNeeds together with the NGO CBM [34], for service users and caregivers who are planning to lead advocacy initiatives. The toolkit was pre-tested by six self-help groups in Uganda (one of the countries that is at the forefront of service user involvement in LMICs), and was peer-reviewed by a wide range of self-advocates and development workers. The toolkit contends that district policy-makers and programme implementers may respond better to advocacy issues that are raised by people affected themselves.

Mental health activists have stressed the importance of taking a holistic approach, in which not only service users, but also caregivers, the surrounding community and decision-makers are engaged, and in which the socio-cultural context is considered. It is also important to take into account the national picture of service user involvement when developing interventions. For example, interventions must consider whether service user groups already exist whose expertise and experiences can be utilised for future involvement, or whether interventions need to focus heavily on empowerment or the establishment of new service user groups. The importance of considering the traditions and values of the socio-cultural context in the implementation of intervention programmes or capacity-building activities (for example, in terms of gender, level of education, or rural-urban cultures) has also been highlighted by advocacy organisations such as ACMI (see above).

In regards to service planning, development and evaluation, a report in the grey literature by TPO (Transcultural Psychosocial Organisation) Uganda [35] described a successful model to scale up mental health services and trauma support in war-affected communities. The process involved service users in the evaluation process (through focus groups and key informant interviews), and patient support groups. The report recommends that services should be monitored and/or evaluated once a year by a wide range of stakeholders, including service users. The use of peer educators for needle exchange programmes for alcohol and drug abuse in Indonesia has also been described in the grey literature [38].

\section{Limitations}

There were several limitations to this review: 1) in regards to the comprehensiveness of studies included, seven studies were excluded because the full-text papers could not be accessed, and one study had to be excluded based on its language of publication (Korean). This may have resulted in a bias in the types of papers that were included in the review (although due to the low number of excluded studies based on these criteria, this bias is unlikely to be substantial). 2) The quality of studies that were included in the review was weak overall, which will have had an impact on the strength of the evidence. This 
highlights further the need for high-quality research in the area. 3) Systematic reviews are commonly subject to a publication or reporting bias [39-41], whereby only positive outcomes are reported, and unpublished reports are missed. The inclusion of grey literature in the review may have reduced some of this bias, although it is likely that not all eligible resources were identified, given the unsystematic nature of grey literature searches. 4) The review was not listed on an international prospective register of systematic reviews such as PROSPERO (see http://www.crd.york.ac.uk/PROSPERO/), though the original protocol was agreed by all of the co-investigators and is available upon request.

\section{Conclusions}

This systematic review showed that the evidence for how best to involve service users and caregivers in mental health system strengthening in LMICs is not easily accessible in the literature, as well as evidence for the evaluation of user involvement (i.e. how useful or effective user involvement is). Furthermore, despite a few emerging studies, there is still a paucity of high-quality research, especially in regards to service user involvement in the development of policies and strategies, the planning and development of services, the training of health workers in mental health care, and within mental health research. It will therefore be important to develop, test and evaluate models of best practice in the future through rigorous and systematic research. One way in which to do this may be to empower service user organisations to deliver those services that they are best at, which in turn may facilitate the documentation of their best practices.

\section{Additional file}

Additional file 1: PRISMA 2009 Checklist. (DOC 63 kb)

\section{Abbreviations}

ACMI: Action for Mental Illness; Emerald: Emerging mental health systems in low- and middle-income countries; EPHPP: Effective Public Health Practice Project; LMICs: low- and middle-income countries; NGO: non-governmental organisation; PANUSP: Pan-African Network of People with Psychosocial Disabilities; RCT: randomised controlled trial; TPO: Transcultural Psychosocial Organisation; WHO-AIMS: World Health Organization Assessment Instrument for Mental Health Systems; WNUSP: World Network of Users and Survivors.

\section{Competing interests}

GT is supported by the National Institute for Health Research (NIHR) Collaboration for Leadership in Applied Health Research and Care South London at King's College London Foundation Trust. The views expressed are those of the author(s) and not necessarily those of the NHS, the NIHR or the Department of Health. GT is supported by the European Union Seventh Framework Programme (FP7/2007-2013) Emerald project. The authors acknowledge financial support from the Department of Health via the National Institute for Health Research (NIHR) Biomedical Research Centre and Dementia Unit awarded to South London and Maudsley NHS Foundation Trust in partnership with King's College London and King's College Hospital NHS Foundation Trust. HL received funding in the last 5 years from the National Institute of Health Research, European Union, Guy's and St. Thomas'
Charity, London, The Health Foundation, United Kingdom, Arthritis Research UK and the South London Membership Council. SEL has received consulting fees from Lundbeck.

\section{Authors' contributions}

MS led the writing of the manuscript, conducted the database and grey literature searches, reviewed the abstracts of papers, contributed to the full-text review of papers and the data extraction, and carried out the quality assessment of papers. HL reviewed the abstracts and full texts of papers. RK reviewed the abstracts and full texts of papers, and carried out the data extraction. SEL reviewed the abstracts of papers, and carried out the full-text reviews and data extraction for Spanish and Portuguese papers. $\mathrm{CH}$ contributed to the grey literature searches, reviewed the abstracts of papers, and contributed to the full-text review of papers. JM, SR, JL, AA and GT contributed to the writing of the manuscript. All authors contributed to the writing of the manuscript, and read and approved the final manuscript.

\section{Acknowledgements}

The research leading to these results is funded by the European Union's Seventh Framework Programme (FP7/2007-2013) under grant agreement $n^{\circ}$ 305968. The funder had no role in study design, data collection and analysis, decision to publish, or preparation of the manuscript. The partner organizations involved in the Emerald programme are Addis Ababa University (AAU), Ethiopia; Butabika National Mental Hospital (BNH), Uganda; GABO:mi Gesellschaft für Ablauforganisation :milliarium GmBH \& Co. KG (GABO:mi), Germany; HealthNet TPO, Netherlands; King's College London (KCL), United Kingdom (UK); Public Health Foundation of India (PHFI), India; Transcultural Psychosocial Organization Nepal (TPO Nepal), Nepal; Universidad Autonoma de Madrid (UAM), Spain; University of Cape Town (UCT), South Africa; University of Ibadan (UI), Nigeria; University of KwaZulu-Natal (UKZN), South Africa; and World Health Organization (WHO), Switzerland. The Emerald programme is led by Prof Graham Thornicroft at KCL. The project coordination group consists of Prof Atalay Alem (AAU), Prof José Luis Ayuso-Mateos (UAM), Dr Dan Chisholm (WHO), Dr Stefanie Fülöp (GABO:mi), Prof Oye Gureje (UI), Dr Charlotte Hanlon (AAU), Dr Mark Jordans (HealthNet TPO; TPO Nepal; KCL), Dr Fred Kigozi (BNH), Prof Crick Lund (UCT), Prof Inge Petersen (UKZN), Dr Rahul Shidhaye (PHFI), and Prof Graham Thornicroft (KCL). Parts of the programme are also coordinated by Ms Shalini Ahuja (PHFI), Dr Jibril Omuya Abdulmalik (UI), Ms Kelly Davies (KCL), Ms Sumaiyah Docrat $(\mathrm{UCT})$, Dr Catherine Egbe (UKZN), Dr Sara Evans-Lacko (KCL), Dr Margaret Heslin (KCL), Dr Dorothy Kizza (BNH), Ms Lola Kola (UI), Dr Heidi Lempp (KCL), Dr Pilar López (UAM), Ms Debra Marais (UKZN), Ms Blanca Mellor (UAM), Mr Durgadas Menon (PHFI), Dr James Mugisha (BNH), Ms Sharmishtha Nanda (PHFI), Dr Anita Patel (KCL), Ms Shoba Raja (BasicNeeds, India; KCL), Dr Maya Semrau (KCL), Mr Joshua Ssebunya (BNH), Mr Yomi Taiwo (UI), and Mr Nawaraj Upadhaya (TPO Nepal).

The Emerald programme's scientific advisory board includes A/Prof Susan Cleary (UCT), Dr Derege Kebede (WHO, Regional Office for Africa), Prof Harry Minas (University of Melbourne, Australia), Mr Patrick Onyango (TPO Uganda), Prof Jose Luis Salvador Carulla (University of Sydney, Australia), and Dr R Thara (Schizophrenia Research Foundation (SCARF), India).

The following individuals are members of the Emerald consortium: Dr Kazeem Adebayo (UI), Ms Jennifer Agha (KCL), Ms Ainali Aikaterini (WHO), Dr Gunilla Backman (London School of Hygiene and Tropical Medicine; KCL), Mr Piet Barnard (UCT), Dr Harriet Birabwa, (BNH), Ms Erica Breuer (UCT), Mr Shveta Budhraja (PHFI), Amit Chaturvedi (PHFI), Dr Abebaw Fekadu (AAU), Mr Daniel Chekol (AAU), Ms Tigist Eshetu (AAU), Mr Naadir Daniels (UCT), Mr Bishwa Dunghana (TPO Nepal), Ms Gillian Hanslo (UCT), Ms Edith Kasinga (UCT), Ms Tasneem Kathree (UKZN), Mr Suraj Koirala (TPO Nepal), Prof Ivan Komproe (HealthNet TPO), Dr Mirja Koschorke (KCL), Mr Domenico Lalli (European Commission), Mr Nagendra Luitel (TPO Nepal), Dr David McDaid (KCL), Ms Immaculate Nantongo (BNH), Dr Sheila Ndyanabangi (BNH), Dr Bibilola Oladeji $(\mathrm{UI})$, Prof Vikram Patel (KCL), Ms Louise Pratt (KCL), Prof Martin Prince (KCL), Ms M Miret (UAM), Ms Warda Sablay (UCT), Mr Bunmi Salako (UI), Dr Tatiana Taylor Salisbury (KCL), Dr Shekhar Saxena (WHO), Ms One Selohilwe (UKZN), Dr Ursula Stangel (GABO:mi), Prof Mark Tomlinson (UCT), and Ms Elaine Webb (KCL).

\section{Author details}

'King's College London, Institute of Psychiatry, Psychology \& Neuroscience, 16 De Crespigny Park, London, SE5 8AF, UK. ${ }^{2}$ King's College London, Faculty of Life Sciences and Medicine, Academic Rheumatology, Clinical Trials Group, 
Weston Education Centre, 10, Cutcombe Rd., London SE5 9RJ, UK. ${ }^{3}$ Butabika National Referral and Teaching Hospital, Kampala, Uganda. ${ }^{4}$ Special Advisor, BasicNeeds, 158A Parade, Leamington Spa, Warwickshire, CV32 4AE, UK. ${ }^{5}$ Nepal Mental Health Foundation, Kathmandu, Nepal. ${ }^{6}$ Department of Psychiatry, Addis Ababa University, College of Health Sciences, School of Medicine, Addis Ababa, Ethiopia.

\section{Received: 14 June 2015 Accepted: 17 February 2016}

\section{Published online: 01 March 2016}

\section{References}

1. Ennis $L$, Wykes T. Impact of patient involvement in mental health research: longitudinal study. Br J Psychiatry. 2013;203(5):381-6.

2. Evans J, Rose D, Flach C, et al. VOICE: Developing a new measure of service users' perceptions of inpatient care, using a participatory methodology. J Ment Health. 2012;21(1):57-71.

3. Rose D, Evans J, Sweeney A, et al. A model for developing outcomes measures from the perspective of mental health service users. Int Rev Psychiatry. 2011;23(1):41-6.

4. Rose D, Wykes T, Bindman J, et al. Information, consent and perceived coercion: Consumers' views on ECT. Br J Psychiatry. 2005;186:54-9.

5. Sweeney A, Rose D, Clement S, et al. Understanding service user-defined continuity of care and its relationship to health and social measures: A cross-sectional study. BMC Health Serv Res. 2012;12(1):145.

6. Demyttenaere K, Bruffaerts R, Posada-Villa J, Gasquet I, Kovess V, Lepine J, et al. Prevalence, severity, and unmet need for treatment of mental disorders in the World Health Organization World Mental Health Surveys. JAMA. 2004;291 (21): 2581-90.

7. Katontoka S. Users' networks for Africans with mental disorders. Lancet. 2007;370:919-20

8. Robb A. Towards strengthening the rights of persons with psychosocial disabilities in Africa. Cape Town: Pan African Network of People with Psychosocial Disabilities (PANUSP); 2012

9. Semrau M, Evans-Lacko S, Alem A, Ajuso-Mateos J, Chisholm D, Gureje O, Hanlon C, Jordans M, Kigozi F, Lempp H et al. Strengthening mental health systems in low and middle-income countries: the Emerald programme. BMC Medicine. in press.

10. Thomas B, Ciliska D, Dobbins M, Micucci S. A process for systematically reviewing the literature: Providing the research evidence for public health nursing interventions. Worldviews Evid-Based Nurs. 2004;1(3):176-84.

11. Armijo-Olivo S, Stiles C, Hagen N, Biondo P, Cummings G. Assessment of study quality for systematic reviews: a comparison of the Cochrane collaboration risk of bias tool and the effective public health practice project quality assessment tool: methodological research. J Eval Clin Pract. 2012;18:12-8.

12. Harden A, Brunton G, Fletcher A, Oakley A. Teenage pregnancy and social disadvantage: systematic review integrating controlled trials and qualitative studies. Br Med J. 2009;339:b4254. doi:10.1136/bmj.b4254.

13. McBain R, Norton D, Morris J, Yasami M, Betancourt T. The role of health systems factors in facilitating access to psychotropic medicines: A crosssectional analysis of the WHO-AIMS in 63 low- and middle-income countries. PLoS Med. 2012;9(1):e1001166.

14. Boothby $N$, Veatch $M$, Pentes M. Evaluating treatment of Axis I mental health disorders in Aceh, Indonesia. Psychiatrist. 2011;35:248-55.

15. Crabtree S. Medication, healing and resistance in East Malaysia. Ment Health Relig Cult. 2005;8(1):17-25.

16. Hayward R, Cutler P. What contribution can ordinary people make to national mental health policies? Community Ment Health J. 2007;43(5):517-26.

17. Agrest M. La participation de los usuarios en los servicios de salud mental Users' participation in mental health services. Vertex - Revista Argentina de Psiquiatria. 2011;22(100):409-18.

18. de la Espriella R, Bustos M. Construccion de una carta institucional de deberes y derechos de pacientes con enfermedad mental - Construction of an institutional declaration of duties and rights of mentally ill patients. Revista Colombiana de Psiquiatria. 2013;42(3):266-75.

19. Ardila S. La inclusion de la perspectiva de los usuarios en los servicios de Salud Mental - Users' perspective inclusion in mental health services evaluation. Vertex - Revista Argentina de Psiquiatria. 2011;22(95):49-55.

20. Camatta M, Nasi C, Adamoli A, Kantorski L, Schneider J. Avaliacao de um Centro de atencao psicossocial: o olhar da familia - evaluation of a psychosocial care center: the view of the family. Cien Saude Colet. 2011;16(11):4405-14.
21. Furtado J, Campos R. Participacao, producao de conhecimento e pesquisa avaliativa: a insercao de diferentes atores em uma investigacao em saude mental - Participation, knowledge production, and evaluative research: participation by different actors in a mental health study. Cad Saude Publica. 2008;24(11):2671-80

22. Malakouti SK, Nojomi M, Panaghi L, Chimeh N, Mottaghipour Y, Joghatai MT, Noorbala AA, Bolhari J. Case-management for patients with schizophrenia in Iran: a comparative study of the clinical outcomes of Mental Health Workers and Consumers' Family Members as case managers. Community Ment Health J. 2009:45(6):447-52.

23. Tripathy P, Nair N, Barnett S, Mahapatra R, Borghi J, Rath S, Gope R, Mahto $D$, Sinha $R$, et al. Effect of a participatory intervention with women's groups on birth outcomes and maternal depression in Jharkhand and Orissa, India: a cluster-randomised controlled trial. Lancet. 2010;375(9721):1182-92.

24. Petersen I, Baillie K, Bhana A, Mental H. Poverty Research Programme C: Understanding the benefits and challenges of community engagement in the development of community mental health services for common mental disorders: lessons from a case study in a rural South African subdistrict site. Transcult Psychiatry. 2012;49(3-4):418-37.

25. Cohen A, Raja S, Underhill C, Yaro B, Dokurugu A, De Silva M, Patel V. Sitting with others: mental health self-help groups in northern Ghana. Int J Ment Heal Syst. 2012;6(1):1.

26. Aznar A, Gonzalez Castanon D, Olate G. The ITINERIS scale on the rights of persons with intellectual disabilities: development, pilot studies and application at a country level in South America. J Intellect Disabil Res. 2012;56(11):1046-57.

27. Liu B, Sullivan $S G$, Wu Z. An evaluation of needle exchange programmes in China. AIDS. 2007;21 Suppl 8:S123-128.

28. Kleintjes S, Lund C, Swartz L. Organising for self-advocacy in mental health: Experiences from seven African countries. Afr J Psychiatry. 2013;16:187-95.

29. Schilder K, Tomov T, Mladenova M, Mayeya J, Jenkins R, Gulbinat W, Manderscheid R, Baingana F, Whiteford H, Khandelval S, et al. The appropriateness and use of focus group methodology across international mental health communities. Int Rev Psychiatry. 2004;16(1-2):24-30.

30. Singh B, Sarma RK, Skarma DK, Singh V, Arya S. Deepak: Assessment of hospital services by consumers: A study from NDDTC, AllMS, Ghaziabad. Medico-Legal Update. 2005:5(1):1-6.

31. Neznanov NG, Vasilyeva AV. Psychiatry in Russia today. Social dimension. European Psychiatry. 2013;28:1.

32. Ndyanabangi S, Basangwa D, Lutakome J, Mubiru C. Uganda mental health country profile. Int Rev Psychiatry. 2004;16(1-2):54-62.

33. Singh B, Sarma R, Sharma D, Singh V, Deepak S. Assessment of hospital services by consumers: a study from NDDTC, AllMS, Ghaziabad. Medico-Legal Update. 2005;5(1):1-6.

34. Ntulo C. In: BasicNeeds Ca, editor. The self-advocacy tool kit. Kampala: CBM and BasicNeeds; 2010.

35. Baingana F. In: Uganda T, editor. End of project evaluation report - Scaling up of mental health services and trauma support among war-affected communities in Gulu, Kitgum and Pader. Uganda: TPO; 2010.

36. Mutiti A. In: Uganda T, editor. End of project evaluation report for CORDAID supported project in Teso. Uganda: TPO; 2011.

37. BasicNeeds. Mental health and development sustaining impact - Annual impact report: 2009. In: Edited by BasicNeeds. Warwickshire, UK: BasicNeeds; 2009.

38. Yulianti EW, Buana YK. An Indonesian self-help group fights a winning battle against alcohol, drugs and STDs. Adolescence education newsletter. 1999:2(2);8.

39. Ioannidis J. Why most published research findings are false. PLoS Med. 2005;2(8):e124.

40. Harris M. Research papers should omit their authors' affiliations. Br Med J. 2014;349:96439. doi:10.1136/bmj.g6439.

41. Syed S, Dadwal V, Martin G. Reverse innovation in global health systems: towards global innovation flow. Glob Health. 2013;9:36.

42. Moher D, Liberati A, Tetzlaff J, Altman D. The PRISMA Group: Preferred reporting items for systematic reviews and meta-analyses: The PRISMA statement. PLoS Med. 2009;6(6):e1000097. 